\title{
Anticorpos anti Brucella abortus, anti Brucella canis e anti Leptospira spp. em raposas (Pseudalopex vetulus) do semiárido paraibano, Nordeste do Brasil
}

\author{
Detection of anti Brucella abortus, anti Brucella canis and anti Leptospira spp. Antibodies in \\ hoary foxes (Pseudalopex vetulus) from semi-arid of Paraiba state, \\ Northeastern region of Brazil
}

\author{
Sérgio Santos de Azevedo ${ }^{\mathrm{I}}$ Maria Luana Cristiny Rodrigues Silva ${ }^{\mathrm{I}}$ \\ Carolina de Sousa Américo Batista ${ }^{\text {II }}$ Albério Antônio de Barros Gomes ${ }^{\mathrm{I}}$ \\ Sílvio Arruda Vasconcellos ${ }^{\mathrm{II}}$ Clebert José Alves ${ }^{\mathrm{I}}$
}

RESUMO

O objetivo do presente trabalho foi determinar a ocorrência de anticorpos anti Brucella abortus, anti Brucella canis e anti Leptospira spp. em raposas (Pseudalopex vetulus). Para tanto, foram utilizadas 60 raposas atropeladas em rodovias no semiárido da Paraíba, Nordeste do Brasil. Para a deteç̧ão de anticorpos anti Brucella abortus, o teste do antígeno acidificado tamponado (AAT) foi empregado como teste de triagem, e a prova do 2-mercaptoetanol foi empregada como método confirmatório. Para o diagnóstico sorológico das infecções por Brucella canis e Leptospira spp., foram utilizados os testes de imunodifusão em gel de agar (IDGA) $e$ soroaglutinação microscópica, respectivamente. Todas as amostras foram negativas na pesquisa de anticorpos anti Brucella canis e anti Leptospira spp. Das 60 raposas testadas, $16(26,6 \%)$ foram positivas para anticorpos anti Brucella abortus no teste de AAT, e quatro (6,7\%) amostras foram confirmadas no teste de 2-mercaptoetanol, sendo duas amostras com título 100 e duas com título 50.

Palavras-chave: sorologia, brucelose, leptospirose, canídeos silvestres.

\section{ABSTRACT}

The aim of this research was to determine the occurrence of anti Brucella abortus, anti B. canis and anti Leptospira spp. antibodies in foxes (Pseudalopex vetulus). Sixty road-killed wild foxes from semi-arid of Paraiba state, Northeastern region of Brazil, were used. For the detection of anti B. abortus antibodies, the buffered plate agglutination test (BPAT) was applied as a screening method and the 2mercaptoethanol test as a confirmatory method. For serological diagnosis of infections by B. canis and Leptospira spp., the agar gel immunodiffusion test (AGID) and the microscopic agglutination test (MAT) were used, respectively. All samples were negative for anti B. canis and anti Leptospira spp. antibodies. Of the 60 foxes tested, 16 (26.6\%) were positive for anti B. abortus antibodies at BPAT, four (6.7\%) samples were confirmed in the 2-mercaptoethanol test, and two samples presented titer 100 and two titer 50.

Key words: serology, brucellosis, leptospirosis, wild canids.

A raposa-do-campo (Pseudalopex vetulus), também conhecida como raposa do Nordeste ou raposa grisalha, é um canídeo silvestre nativo do Brasil (DALPONTE, 1995) e encontrado comumente no semiárido nordestino. Possui atividade principalmente noturna e se alimenta de aves, pequenos roedores e insetos. No entanto, é comum o relato de proprietários rurais acerca do predadorismo de cordeiros e cabritos.

O potencial das raposas como possíveis transmissores de zoonoses foi evidenciado em trabalhos conduzidos no Brasil. GENNARI et al. (2004) relataram uma soropositividade de anticorpos anti

'Unidade Acadêmica de Medicina Veterinária, Centro de Saúde e Tecnologia Rural, Universidade Federal de Campina Grande (UFCG). Av. Universitária, s/n, Bairro Santa Cecília, CP 64, 58700-970, Patos, PB, Brasil. E-mail: sergio@vps.fmvz.usp.br. *Autor para correspondência.

"Departamento de Medicina Veterinária Preventiva e Saúde Animal, Faculdade de Medicina Veterinária e Zootecnia (FMVZ), Universidade de São Paulo (USP), São Paulo, SP, Brasil. 
Toxoplasma gondii de 60\% (9/15) em raposas Cerdocyon thous de São Paulo e do Paraná. GOMES (2004) isolou vírus rábico a partir do cérebro de 12 raposas Pseudalopex vetulus atropeladas em rodovias dos Estados da Paraíba, de Pernambuco e do Rio Grande do Norte. Utilizando esses 12 animais, SILVA et al. (2009) isolaram vírus rábico das glândulas salivares de todos eles.

Brucella abortus é o principal agente etiológico da brucelose bovina, doença bacteriana de evolução crônica e caráter granulomatoso difuso, caracterizada pela infecção de células do sistema mononuclear fagocitário, e representa em todo o mundo um problema sanitário e econômico (PAULIN \& FERREIRA NETO, 2003). Nos seres humanos, a brucelose é uma antropozoonose de caráter principalmente ocupacional, e os indivíduos mais expostos são os que trabalham diretamente com os animais infectados (tratadores, proprietários e veterinários) ou com produtos de origem animal (magarefes e laboratoristas) (DOGANAY \& AYGEN, 2003).

As espécies silvestres, principalmente as unguladas, são reservatórios naturais da Brucella abortus e desempenham importante papel na epidemiologia da doença, pois são os mantenedores do agente no ambiente silvestre (PAULIN \& FERREIRA NETO, 2003). Em condições naturais, as brucelas já foram isoladas de uma grande variedade de espécies silvestres, incluindo raposas (SZYFRES \& GONZALEZ TOME, 1966; DAVIES et al., 1973).

No Brasil, não existem relatos da ocorrência de raposas Pseudalopex vetulus soropositivas para B. abortus, B. canis e Leptospira spp. O objetivo do presente trabalho foi pesquisar anticorpos contra esses agentes em raposas do semiárido paraibano.

Foram utilizadas 60 raposas (Pseudalopex vetulus) atropeladas nas rodovias do semiárido paraibano, no período de março a agosto de 2004. As rodovias onde foram recolhidas as raposas atropeladas são aquelas que cortam o semiárido do Estado da Paraíba, nas proximidades do Município de Patos, localizado a $320 \mathrm{~km}$ do litoral, entre as latitudes Sul 0646'19” e 07³8'32" e longitudes Oeste - 36²' $52^{\circ}$ ” e 3808'56”. As rodovias foram: BR 230, que liga Patos a Pombal e Patos a Santa Luzia; BR 361, que liga Patos a Itaporanga; BR 110, que liga Patos a Teixeira; e PB 230, que liga Desterro a Tavares.

Para o recolhimento dos animais atropelados, foi utilizada a frota de veículos que servem a região para transporte alternativo. Cada motorista voluntário que aderiu ao estudo foi alertado dos riscos de transmissão de doenças, recebeu instruções sobre os procedimentos a serem tomados e recebeu também luvas e sacos plásticos para o recolhimento seguro dos cadáveres. Para a obtenção de soro sanguíneo, foi coletado coágulo da cavidade cardíaca. O material foi enviado ao Laboratório de Doenças Transmissíveis (LDT) da Universidade Federal de Campina Grande (UFCG), campus de Patos, onde foi realizada a centrifugação para obtenção do soro, e posterior estocagem a $-20^{\circ} \mathrm{C}$, até a realização dos exames sorológicos.

Para a pesquisa de anticorpos anti $\boldsymbol{B}$. abortus, o teste do Antígeno Acidificado Tamponado (AAT) foi utilizado como prova de triagem, e os soros que reagiram positivamente foram submetidos à prova do 2-mercaptoetanol (BRASIL, 2001).

O teste de imunodifusão em gel de agar, utilizando kits produzidos pelo Instituto de Tecnologia do Paraná (TECPAR) e empregando antígeno de lipopolissacarídeos e proteínas de Brucella ovis, amostra Reo 198, foi utilizado no diagnóstico sorológico da infecção por B. canis. A técnica foi executada de acordo com as recomendações do fabricante.

O diagnóstico sorológico da infecção por Leptospira spp. foi realizado pela técnica de soroaglutinação microscópica (SAM), de acordo com GALTON et al. (1965) e COLE et al. (1973), com uma coleção de antígenos vivos composta por 22 sorovares patogênicos e dois saprófitos: Australis, Bratislava, Autumnalis, Butembo, Castellonis, Bataviae, Canicola, Whitcombi, Cynopteri, Grippotyphosa, Hebdomadis, Copenhageni, Icterohaemorrhagiae, Javanica, Panamá, Pomona, Pyrogenes, Hardjo, Wolffi, Shermani, Tarassovi, Andamana, Patoc e Sentot. Os soros foram triados na diluição de 1:100, e aqueles que apresentaram $50 \%$ ou mais de aglutinação foram titulados pelo exame de uma série de diluições geométricas de razão dois. $\mathrm{O}$ título do soro foi a recíproca da maior diluição que apresentou resultado positivo.

Todas as amostras de soro analisadas $(n=60)$ foram negativas para anticorpos anti Brucella canis e anti Leptospira spp. Para B. abortus, 16 (26,6\%) amostras foram positivas no AAT, e quatro $(6,7 \%)$ foram confirmadas na prova do 2-mercaptoetanol, sendo duas amostras com título 100 e duas com título 50 .

Foram detectados anticorpos anti Brucella abortus em raposas de várias partes do mundo, bem como foi realizado o isolamento do agente. SZYFRES \& GONZÁLEZ TOME (1966) obtiveram soropositividade de 23,8\% em raposas Dusicyon gymnocercus antiquus e Dusicyon griséus griseus, nos distritos de Azul e Olavarria, Buenos Aires, com 11,3\% das amostras positivas apresentando títulos $=100$, 
sendo isolada B. abortus biotipo 1 de animais soropositivos. DAVIES et al. (1973) testaram 87 raposas vermelhas (Vulpes vulpes) de uma área do país de Gales onde a brucelose bovina era endêmica e encontraram anticorpos anti Brucella abortus em oito (9,2\%). Nesse trabalho, B. abortus biotipo 1 foi isolada de uma raposa soropositiva. Na Califórnia, McCUE \& O’FARRELL (1988) encontraram anticorpos anti Brucella abortus em três (13\%) de 23 raposas Vulpes macrotis mutica, no período de 1981 e 1982. Na Argentina, no período de 1998 a 2001, MARTINO et al. (2004) relataram soropositividade de $18 \%$ em raposas Dusicyon culpaeus e Dusicyon griseus da região da Patagônia.

No presente trabalho, embora não tenha sido conduzida a tentativa de isolamento do agente, há um forte indício de que as raposas estavam naturalmente infectadas dada a elevada sensibilidade e especificidade dos testes sorológicos em série (AAT e 2-mercaptoetanol) empregados, em torno 95 e 99,5\%, respectivamente (AZEVEDO, 2006), utilizados oficialmente no Brasil para o diagnóstico sorológico da brucelose bovina como parte integrante das ações do Programa Nacional de Controle e Erradicação da Brucelose e Tuberculose Bovina (PNCEBT), instituído em 2001.

A ocorrência de raposas soropositivas para B. abortus sugere a possibilidade de infecção natural nesses animais e levanta preocupações, uma vez que a ocorrência de animais silvestres infectados pode dificultar o sucesso do PNCEBT, dada a possibilidade de contato com bovinos submetidos a manejo extensivo. Sugere-se que novos estudos sejam conduzidos em raposas atropeladas com os objetivos de isolar o agente e confirmar a infecção nesses animais, tendo em vista a adoção de medidas que impeçam o prejuízo do PNCEBT.

\section{REFERÊNCIAS}

AZEVEDO, S.S. Caracterização epidemiológica da brucelose bovina no Estado do Espírito Santo. 2006. 103f. Tese (Doutorado em Medicina Veterinária) - Curso de Pósgraduação em Epidemiologia Experimental e Aplicada às Zoonoses, Universidade de São Paulo, SP.

BRASIL. Ministério da Agricultura, Pecuária e Abastecimento. Departamento de Defesa Animal. Programa Nacional de Controle e Erradicação da Brucelose e Tuberculose Animal (PNCEBT). Inquérito soroepidemiológico da brucelose Manual de procedimentos. Brasília, 2001. 20p.

COLE, J.R. et al. Improved microtechnique for the leptospiral microscopic agglutination. Applied Microbiology, v.25, n.6, p.976-
980, 1973. Disponível em: <http://www.pubmedcentral.nih.gov/ picrender.fcgi? artid=380950\&blobtype $=$ pdf $>$. Acesso em: 18 set. 2009.

DAVIES, G.J.H. et al. Isolation of Brucella abortus from a Fox (Vulpes vulpes). State Veterinary Journal, v.28, p.250252, 1973.

DALPONTE, J.C. The hoary fox in Brazil. Canid News, v.3, p.23-24, 1995.

DOGANAY, M.; AYGEN, B. Human brucellosis: an overview. International Journal of Infectious Diseases, v.7, n.3, p.173-182, 2003. Disponível em: <http://www.ijidonline.com/ article/S1201-9712(03)90049-X/pdf >. Acesso em: 12 ago. 2009.

GALTON, M.M. et al. Application of a microtechnique to the agglutination test for leptospiral antibodies. Applied Microbiology, v.13, p.81-85, 1965. Disponível em: <http:// w w w. p u b m e d c e n t r l. n i h. g o v/ picrender.fcgi?artid=1058195\&blobtype $=$ pdf $>$. Acesso em: 18 set. 2009.

GENNARI, S.M. et al. Seroprevalence of Toxoplasma gondii antibodies from wild canids from Brazil. Veterinary Parasitology, v.121, p.337-340, 2004. Disponível em: <http:/ /dx.doi.org/10.1016/j.vetpar.2004.02.023>. Acesso em: 23 jul. 2009. doi: 10.1016/j.vetpar.2004.02.023.

GOMES, A.A.B. Epidemiologia da raiva: caracterização de vírus isolados de animais domésticos e silvestres do semi-árido paraibano da região de Patos, Nordeste do Brasil. 2004. 107f. Tese (Doutorado em Medicina Veterinária) - Curso de Pós-graduação em Epidemiologia Experimental e Aplicada às Zoonoses, Universidade de São Paulo, SP.

MARTINO, P.E. et al. Serological survey of selected pathogens of free-ranging foxes in southern Argentina, 1998-2001. Revue Scientifique et Technique Office International des Epizooties, v.23, n.3, p.801-806, 2004.

McCUE, P.M.; O’FARRELL, T.P. Serological survey for selected diseases in the endangered San Joaquin kit fox (Vulpes macrotis mutica). Journal of Wildlife Diseases, v.24, n.2, p.274-281, 1988.

PAULIN, L.M.; FERREIRA NETO, J.S. A experiência brasileira no combate à brucelose bovina. Jaboticabal: Funep, 2003. 154p.

SILVA, M.L.C.R. et al. Isolation of rabies vírus from the parotid salivary glands of foxes (Pseudalopex vetulus) from Paraíba State, Northeastern Brazil. Brazilian Journal of Microbiology, v.40, p.446-449, 2009. Disponível em: <http:/ /www.scielo.br/scielo.php?script=sci_arttext \&pid $=$ S 1 $5183822009000300004 \& \operatorname{lng}=e n \& n r m=i s o \& \operatorname{lng}=e n>$. Acesso em: 16 set. 2009. doi: 10.1590/S1517-83822009000300004.

SZYFRES, B.; GONZALEZ TOME, J. Natural Brucella infection in Argentine wild foxes. Bulletin of the World Health Organization, v.34, n.6, p.919-923, 1966. 